\title{
KAJIAN CAPAIAN PROGRAM MAHASISWA WIRAUSAHA
}

\author{
Hartono \\ Jurusan Akuntansi Program Studi Akuntansi Politeknik Negeri Semarang, \\ Jl. Prof. Sudarto, SH Tembalang Semarang 50275
}

\begin{abstract}
Student Entrepreneur Program ( PMW Program) conducted since 2009 need to be evaluated it's achievement so that the improvement can be arranged. The aspect evaluation is stressed on changed of attiude, paradigm, and committment of student in entrepreneur profession. The population of this research is student participated PMW program from all of politechnic, university, and high school arroud Indonesia. Respondent was elected by purposive random sampling i.e that assumed the best because of being delegation of their politechnic in KMI expo on 2016 that held by Brawijaya Unversity Malang.

The data was collected by questionaire that designed for explore and identify the tendency student being serious and commit on entrepreneur profession. Data processing result that 99\% respondent believe in prospective entrepreneur profession so that better to start business since study in campus ( $81 \%$ ) althought they faced dilemma of academic obligation (64\% ). They still believed that the main factor of entrepreneur is money as capital ( 76\%), however this statement was supported by the fact that $92 \%$ respondent confession that their participation on PMW program because of start up fund. The committment on entrepreneur become nonsense because majority of partipant would seek a job when finished their study and would start business if do not getting job yet.
\end{abstract}

Keywords: entrepreneur, commitment

Abstrak: Program Wirausaha Mahasiswa ( PMW ) yang sudah terselenggara sejak 2009 perlu dievaluasi keberhasilannya sehingga dapat dilakukan langkah penyempurnaan program. Sesuai dengan tujuan program maka aspek evaluasinya adalah menekankan pada perubahan sikap, cara pandang, dan komitmen mahasiswa peserta program terhadap profesi wirausaha. Populasi penelitian ini adalah seluruh mahasiswa peserta program yang tersebar di seluruh PTN dan sebagian PTS di Indonesia, sedangkan sampel yang diambil adalah sebanyak 100 responden. Pemilihan responden dilakukan secara purposive random sampling, yaitu dengan kriteria yang dianggap berhasil dan dipilih oleh perguruan tingginya mewakili ekspo kewirausahaan mahasiswa Indonesia yang pada tahun 2016 diselenggarakan di Universitas Brawijaya Malang.

Hasil olah data mengindikasikan bahwa hampir semua responden ( $99 \%$ ) percaya bahwa wirausaha merupakan profesi yang prospektif sehingga ber pendapat bahwa berwirausaha sebaiknya dimulai sejak mahasiswa ( $81 \%$ ), meskipun disisi lain mereka gamang dengan benturan kepentingan/kewajiban akademis ( $64 \%$ ). Pandangan terhadap modal utama berwirausaha masih terkunci pada modal uang ( $76 \%$ ), dimana hal ini diperkuat dengan jawaban $92 \%$ responden yang mengakui bahwa mereka berwirausaha karena adanya bantuan modal PMW. Komitmen berwirausaha terasa hambar bila mendengar jawaban mereka bahwa akan tetap mencari/melamar pekerjaan ( $92 \%$ ) setelah selesai kuliah nanti , dan baru akan berwirausaha ( $75 \%$ ) bila belum juga mendapatkan pekerjaan.

Kata kunci ; wirausaha , komitmen 


\section{Pendahuluan}

Data dari Badan Pusat Statistik ( BPS 2015 ) menyebutkan bahwa tingkat pengangguran terbuka di Indonesia pada tahun 2015 mencapai $6,9 \%$ atau 8,15 juta dimana persentase terbesar adalah lulusan perguruan tinggi, yaitu $21,5 \%$. Kondisi tersebut diatas didukung oleh kenyataan bahwa sebagian besar lulusan perguruan tinggi cendwrung lebih sebagai pencari kerja ( job seeker ) dari pada pencipta lapangan kerja ( job creator ). Hal ini kemungkinan disebabkan system pendidikan dan pembelajaran yang diterapkan di berbagai perguruan tinggi saat ini masih terfokus pada bagaimana menyiapkan para mahasiswa yang cepat lulus dan mendapatkan pekerjaan, bukannya lulusan yang yang siap menciptakan pekerjaan.

Ketua center of entrepreneur Development UGM menyebutkan kewirausahaan menjadi suatu hal yang harus diberikan di perguruan tinggi. Dengan adanya pembelajaran kewirausahaan diharapkan mampu Mengurangi tingginya angka pengangguran, khususnya dari kalangan terdidik ( sarjana dan diploma ). Pendidikan kewirausahaan untuk meningkatkan spirit dan mengembangkan skill serta knowledge di kalangan mahasiswa agara mereka punya bekal setelah lulus nantinya

Dengan maksud untuk menghasilkan lulusan yang mampu menciptakan lapangan kerja maka dirasa perlu untuk menumbuh kembangkan jiwa dan semangat kewirausahaan dikalangan mahasiswa. Adanya mata kuliah Kewirausahaan dalam kurikulum dirasa belum cukup , sehingga kemendikbud ( waktu itu ) mengembangkan berbagai kebijakan yang salah satunya adalah program mahasiswa wirausaha ( PMW) sejak 2009. PMW sebagai bagian dari strategi pendidikan kewirausahaan di perguruan tinggi dimaksudkan untuk memfasilitasi para mahasiswa yang mempunyai minat berwirausaha dan memulai usaha dengan basis ilmu pengetahuan, teknologi, dan seni. Fasilitas yang diberikan meliputi pendidikan dan pelatihan kewirausahaan, magang usaha , penyusunan rencana bisnis, dukungan permodalan dan pendampingan serta keberlanjutan usaha. Program ini diharapkan mampu mendukung visi dan misi pemerintah dalam mewujudkan kemandirian bangsa melalui penciptaan lapangan kerja dan pemberdayaan potensi ekonomi bangsa.

\section{Rumusan Masalah}

Direktorat Jendral Pendidikan Tinggi

Kemendiknas Dikti (dulu

Kemendikbud) sejak 2009 meluncurkan program PMW dengan harapan akan terlahir wirausahawirausaha terdidik dari dunia perguruan tinggi yang akan berdampak pada pengurangan angka pengangguran terutama dari tingkat sarjana dan diploma. Setelah PMW berjalan 7 tahun perlu dilakukan evaluasi guna mengetahui apakah tujuan yang dicanangkan program ini dapat direalisasikan ataukah tidak. Hasil penelitian ini diharapkan dapat digunakan oleh pihak yang berkepentingan sebagai salah satu informasi dalam menentukan kebijakan dimasa mendatang terkait kewirausahaan mahasiswa.

\section{Hasil Penelitian Terdahulu}

Profesi wirausaha merupakan profesi yang menantang karena disatu sisi memberikan harapan penghasilan yang besar namun disisi lain melekat resiko berupa ketidak pastian yang juga besar. Mungkin karena alasan tersebut maka minat masyarakat untuk berwirausaha realtif masih rendah, hal ini terlihat dari angka proporsi wirausahawan yang masih dibawah $2 \%$, angka yang secara konsensus disepakati sebagai syarat suatu negara untuk mampu bersaing. Rendahnya minat berwirausaha pada angkatan kerja muda, khususnya dari 
kalangan terdidik (baik yang masih mahasiswa maupun yang sudah lulus) menarik untuk dilakukan penelitian guna mengidentifikasi variabel apa saja yang sebenarnya menjadi pemicunya.

Lieli Suharti dan Hani Sirene melakukan penelitian untuk mengetahui pengaruh berbagai faktor, baik yang menyangkut factor internal maupun konteksual terhadap niat kewirausahaan ( entrepreneurship intention ) mahasiswa. Faktor internal meliputi karakteristik individual ( socio demography ), factor sikap ( attitude ) , sedangkan factor konsepsual mencakup partisipasi mahasiswa dalam kegiatan terkait kewirausahaan di kampus. Populasi penelitian ini adalah mahasiswa Universitas Satya Wacana Salatiga dengan sampel berupa mahasiswa yang pernah mengikuti kegiatan seminar maupun pelatihan kewirausahaan. Adapun responden yang diambil sejumlah 300 orang. Hasil penelitian menyebutkan bahwa factor sosio demogafi yang mempengaruhi niat kewirausahaan mahasiswa adalah profesi orangtua sebagai wirausahawan dan pengalaman mahasiswa yang bersangkutan dalam berwirausaha. Kemudian faktor sikap individu yang berpengaruh adalah otoritas keputusan dan kemampuan bekerja keras. Sedangkan factor konteksual yang berpengaruh adalah academic support dan socil support. Satu hal yang menarik dari hasil penelitian ini adalah bahwa unsur keikutsertaan mahasiswa dalam kegiatan pelatihan/pendidikan kewirausahaan ternyata tidak berpengaruh terhadap niat kewirausahaan mahasiswa.

Penelitian lain terkait minat berwirausaha dilakukan oleh Anandha dan Taufik pada mahasiswa Universitas Trunojoyo Madura dengan mengambil 400 responden. Penelitian mencoba untuk memetakan karakteristik kewirausahaan UTM yang terdiri atas variabel kebutuhan akan prestasi, efikasi diri (kepribadian ), akses terhadap modal dan informasi
, serta latar belakang orang tua. Hasil penelitian menunjukkan bahwa kendala minat mahasiswa menjadi wirausahawan adalah minimnya pengalaman berwirausaha , keterbatasan modal , rendahnya keberanian mengambil resiko, dan latar belakang orang tua yang bukan wirausahawan.

\section{Program Mahasiswa Wirausaha}

Kewirausahaan dimaknai sebagai semangat, sikap dan perilaku atau kemampuan seseorang dalam melihat peluang, menangani usaha dan ataukegiatan yang mengarah pada upaya mencari, menciptakan, menerapkan cara kerja, teknologi dan produk baru dengan meningkatkan efisiensi dalam rangka memberikan pelayanan yang lebih baik dan atau memperoleh keuntungan yang lebih besar. Kewirausahaan juga merupakan sutau proses kreatifitas dan inovasi yang mempunyai resiko tinggi untuk menghasilkan nilai tambah bagi produk yang bermanfaat bagi mayarakat dan mendatangkan kemakmuran bagi wirausahawan. Pendidikan yang diwujudkan dalam PMW bertujuan nntuk membentuk soft skill agar berperilaku sesuai karakter wirausaha. Tiga tahapan dalam perkembangan teori kewirausahaan, yaitu ;

1. teori yang mengutamakan peluang usaha. Teori ini disebut teori ekonomi, yaitu perilaku wirausaha akan muncul dan berkembang apabila ada peluang ekonomi.

2. Teori yang mengutanakan tanggapan orang terhadap peluang, yaitu ;

a. teori sosiologi, yang mencoba menerangkan mengapa beberapa kelompok social menunjukkan tanggapan yang berbeda terhadap peluang usaha

b. teori psikologi, yang mencoba menjawab karakteristik perorangan yang membedakan wirausaha berhasil dan tidak berhasil. 
3. teori yang mengutamakan hubungan perilaku wirausaha dengan hasilnya. Teori perilaku ini mencoba memahami pola perilaku dengan keyakinan bahwa wirausaha dapat dipelajari.

Selama ini minat mahasiswa untuk menjadi berwirausaha masih terbatas , dimana hal ini terjadi karena adanya perasaan ketidak pastian karir menjadi pengusaha. Kietidak pastian ini sesungguhnya dapat disiasati dengan mengenalkan langsung para mahasiswa kepada pengusaha yang sukses. ( dosen FEB ;Dr Sahid S Nugroho ). Salah satu upaya untuk mendukung mahasiswa agar berminat menjadi wirausaha adalah dengan disediakannya fasilitas start up business sebagai modal awal bagi mereka. Bentuknya bisa berupa infrastruktur

Program PMW bertujuan untuk mencetak wirausaha baru dari kalangan terdidik ( perguruan tinggi) agar lulusan perguruan tinggi tidak hanya mencari pekerjaan. PMW sebagai bagian dari strategi pendidikan kewirausahaan di perguruan Tinggi, dimaksudkan untuk memfasilitasi mahasiswa yang mempunyai minat wirausaha dan memulai usaha berbasis iptek dan seni. Fasilitas yang diberikan meliputi pendisikan dan pelatihan kewirausahaan , magang, penyusunan rencana bisnis , dukungan pendampingan dan konsultasi bisnis.

PMW mulai diluncurkan pada tahun anggaran 2009 dengan mekanisme pemberian alokasi anggaran dari kemendikbud ke setiap perguruan tinggi dengan dana sejumlah lima ratus juta rupiah untuk tingkat politeknik/akademi dan sampai satu setengah milyar rupiah untuk tingkat universitas. Mahasiswa yang berminat direkrut dengan seleksi ketat dimana mereka yang lolos kemudian diberikan pelatihan dan pendidikan kewirausahaan. Kemudian mereka diminta membuat rencana bisnis untuk dikompetisikan dimana proposal yang layak akan mendapatkan bantuan dana untuk start up business.
Lembaga atau panitia yang dibentuk perguruan tinggi melakukan pendampingan dan monitoring guna memastikan jalannya usaha yang dijalankan mahasiswa tersebut.

Profesi wirausaha dapat diandalkan Data tabulasi menunjukkan bahwa 99\% responden meyakini bahwa wirausaha dapat dijadikan sandaran dalam mencari nafkah penghidupan dan hanya $1 \%$ responden yang merasa kurang yakin. Hal ini mengindikasikan pengakuan dan kesadaran responden akan potensi yang dapat dihasilkan profesi wirausaha, dimana keyakinan tersebut berkembang setelah mereka mengikuti program PMW. Dengan demikian dapat diharapkan bahwa mereka mempertimbangkan secara sungguh-sungguh untuk menekuni profesi wirausaha .

Wirausaha sejak kuliah

Data tabulasi menunjukkan bahwa $81 \%$ responden berpendapat bahwa berwirausaha sebaiknya dimulai sejak muda ( masih kuliah) dan sedangkan $19 \%$ responden kurang/ tidak sependapat. Hal ini mengindikasikan bahwa partisipasi sebagian besar peserta program PMW berpartisipasi didasarkan pada keinginan untuk merintis berwirausaha. Disisi lain masih terdapat $19 \%$ peserta program PMW yang berpendapat bahwa berwirausaha dimulai nanti saja bila telah menyelesaikan kuliahnya. Kondisi ini dapat di cek silang dengan jawaban atas pernyataan berikutnya, yaitu tentang apakah berwirausaha dapat mengganggu konsentrasi kuliah. Kuliah faktor penghambat

Data tabulasi menunjukkan bahwa sebagian besar responden ( $84 \%$ ) berpendapat bahwa aktifitas perkuliahan bukan menjadi penghalang/hambatan dalam menjalankan bisnis , sedangkan sisanya ( $16 \%)$ berpendapat sebaliknya. Dikaitkan dengan jawaban pernyataan sebelumnya maka terlihat adanya konsistensi yaitu bahwa sebaiknya berwirausaha dimulai sejak mahasiswa karena diyakini tidak akan 
mengganggu konsentrasi belajar. Demikian pula konsistensi jawaban mereka yang berpendapat bahwa berwirausaha membutuhkan keseriusan sehingga tidak bisa dilakukan sambil kuliah.

Motivasi turun karena peluang usaha susah

Data tabulasi menunjukkan bahwa hanya $\quad 31 \%$ responden yang menyatakan bahwa motivasi berwirausaha mereka dipengaruhi oleh sulitnya mencari peluang usaha , sedangkan responden lain tidak begitu terpengaruh. Ini berarti bahwa $69 \%$ responden memiliki motivasi tinggi dalam berwirausaha , sehingga kendala yang dihadapi ( peluang usaha sulit, kompetisis kuat dan lain-lain ) merupakan keniscayaan dalam bisnis.

Uang menjadi modal utama wirausaha Data tabulasi menunjukkan bahwa masih sebanyak sepertiga responden yang berpendapat bahwa modal utama berwirausaha adalah uang, hal ini mengindikasikan masih rendahnya kesadaran responden terhadap modal selain uang. Untungnya masih dua per tiga responden yang meyakini bahwa uang hanyalah salah satu modal berwirausaha, sehingga kepada mereka masih dapat digantungkan asa kewirausahaan mahasiswa.

Berwirausaha karena ada bantuan modal PMW

Data tabulasi menunjukkan bahwa mayoritas responden ( $92 \% \quad)$ termotivasi berwirausaha karena ada bantuan dana atau modal. Hal ini mengindikasikan bahwa bagi mahasiswa modal ( dalam artian uang ) untuk memulai usaha ( start up business ) masih merupakan kendala. Hanya 8\% responden yang tidak sependapat, barangkali mereka telah merintis bisnis sebelum mengikuti program PMW.

Kompetisi bisnis merupakan ancaman Data tabulasi menunjukkan bahwa masih ada $25 \%$ responden yang beranggapan bahwa kompetisi bisnis adalah ancaman, sedangkan yang $75 \%$ memandangnya sebagai suatu keniscayaan dalam bisnis. Argumen guna menjelaskan hal ini adalah bahwa sebagian besar responden baru pertama kali mencoba berbisnis sehingga masih 'alergi' dengan kompetisi.

Bimbingan dosen menentukan keberhasilan usaha

Data tabulasi menunjukkan bahwa responden sebanyak $82 \%$ masih membutuhkan pembimbingan dari dosen dalam menjalankan bisnisnya dimana hal ini karena berwirausaha merupakan pengalaman pertama. Hanya 18\% responden yang percaya diri menyatakan bahwa bimbingan dosen hanya sesekali diperlukan.

Tertib admin usaha

Data tabulasi menunjukkan bahwa responden menyadari aspek tertib administrasi dalam berwirausaha menentukan keberhasilan berwirausaha. Hal ini merupakan refleksi dari bekal ilmu yang mereka peroleha dari proses kuliah. Ini menjadi pembeda terhadap wirausaha yang tidak berlatar belakang pendidikan tinggi.

Wirausaha semasa kuliah hanya cari pengalaman

Data menunjukkan bahwa $76 \%$ responden memutuskan berwirausaha melalui program PMW dengan niat untuk merintis bisnis karena percaya bahwa berwirausaha dapat dijadikan sumber penghidupan. Namun $24 \%$ responden ternyata tidak serius dalam mengikuti program PMW, mereka hanya berniat mendapatkan pengalaman baru sehingga hampir dapat dipastikan tidak akan memilih profesi wirausaha.

Lulus kuliah tetap cari kerja

Data tabulasi jawaban menunjukkan bahwa sebanyak $62 \%$ responden memberikan sinyal akan tetap berwirausaha karena mereka tidak berniat untuk mencari pekerjaan formal di perusahaan maupun instansi pemerintah. Sebaliknya masih banyak ( $38 \%$ ) responden yang tidak mantap 
berwirausaha sehingga masih berniat untuk mencari pekerjaan setelah lulus. Orangtua berperan dlam keputusan wirausaha

Data tabulasi menunjukkan bahwa sebagiab besar responden ( $83 \%$ ) mengakui bahwa orang tua sangat menentukan keputusan mereka jika kan berwirausaha, hanya sebagian kecil ( $17 \%$ ) saja yang mampu untuk mengambil keputusan berwirausaha tanpa harus mengikuti kemauan orang tua.

Kreatifitas lebih penting dibanding jaringan

Data tabulasi menunjukkan peran kreatifitas relative berimbang dengan peran membangun jaringan dalam menentukan keberhasilan berwirausaha. Sebagian ( 60\%) lebih menekankan unsur kreatifitas sedangkan sebagian lainnya ( $40 \%)$ lebih menekankan unsur jaringan.

Tahun pertama rugi baiknya tutup aja Data tabulasi menunjukkan bahwa semangat pantang menyerah dari hampir semua responden dalam mensikapi ketatnya persaingan bahkan ketika tahun pertama masih juga belum menghasilkan keuntungan. Hanya 6\% responden yang terkesan kurang gigih dalam berwirausaha karena akan memutuskan menutup usaha ketika tahun pertama tidak memberikan hasil yang diharapkan.

Berwirausaha bila lulus kuliah belum dapat job

Data tabulasi menunjukkan bahwa 59\% responden berpendapat bahwa seharusnya untuk berwirausaha tidak dilakukan secara terpaksa ( karena tidak ada pekerjaan lain ), hal ini mengindikasikan bahwa kelompok responden ini berpotensi akan berwirausaha. Sebaliknya $41 \%$ responden tegas menyatakan bahwa berwirausaha

Komitmen Untuk Berwirausaha Analisis guna menjelaskan komitmen peserta program PMW untuk menekuni profesi wirausaha dilakukan berdasarkan jawaban responden atas sejumlah pernyataan yang diberikan. Dengan mempelajari rekapitulasi jawaban yang diberikan dapat dipetakan seberapa besar kecenderungan responden untuk konsisten berwirausaha. Responden yang memutuskan untuk terus berwirausaha mengindikasikan bahwa mereka meyakini keandalan profesi wirausaha di masa depan.

Pernyataan pertama dalam kuesioner dimaksudkan untuk mendeteksi tingkat keyakinan responden terhadap wirausaha sebagai profesi yang menjanjikan untuk memperoleh penghidupan. Dan jawaban yang diberikan ternyata mereka mantap ( $99 \%$ ) dengan profesi wirausaha , hanya $1 \%$ yang masih bimbang. Tentunya jawaban tersebut harus didukung oleh indikator lain, yaitu jawaban atas pernyataan berikutnya dalam kuesioner. Kemantapan tersebut diperkuat oleh $86 \%$ responden yang berniat sungguh-sungguh dalam berwirausaha, maksudnya keikutsertaan mereka dalam program PMW bukan sekedar selingan kuliah belaka. Dari kelompok tersebut sebanyak $81 \%$ responden yang berpendapat bahwa berwirausaha sebaiknya dilakukan sejak mahasiswa dimana sebagian besar (69\%) mereka merasa dan percaya bahwa kuliah tidak akan menghambat proses perkuliahan. Ada yang menarik disini yaitu adanya penurunan tingkat kemantapan berwirausaha dikaitkan dengan kekawatiran mereka atas kemampuan pengelolaan waktu antara kuliah dan berwirausaha. Hal ini relative wajar, karena bagaimanapun juga mereka memiliki tanggung jawab untuk menyelesaikan kuliah mereka sehingga tidak mungkin konsentrasi penuh pada bisnis atau berwirausaha. Fakta yang menarik adalah bahwa mereka ( $92 \%$ ) berwirausaha karena adanya bantuan modal dari program PMW, dengan kata lain seandainya tidak ada program PMW bisa jadi mereka tidak atau belum berwirausaha. Kenyataan ini tidaklah aneh karena karakteristik mahasiswa Indonesia pada umumnya adalah bahwa biaya kuliah, termasuk biaya hidup, masih sepenuhnya berasal dari 
orangtua dengan nominal yang relatif terbatas. Dengan demikian masuk akal bila sulit mengharapkan mahasiswa akan berwirausaha dengan modal dari menyisihkan uang bulanannya.

Sebagai mahasiswa mereka memperoleh berbagai ilmu sehingga mempengaruhi cara pandang mereka terhadap kewirausahaan. Mereka $(67 \%$ ) menyadari sepenuhnya bahwa uang hanya salah satu modal berwirausaha, yang lebih penting adalah modal semangat pantang menyerah. Sehingga bila mengalami kegagalan di tahun pertama berbisnis tidak menjadi alasan mereka untuk berhenti ( 94\% responden ) karena yakin kegagalan adalah kesuksesan yang tertunda. Mereka mempelajari bahwa wirausahawan yang sekarang sukses juga pernah mengalami kegagalan beberapa kali, karena dari kegagalan lah maka bisa dihindari kesalahan yang sama di masa mendatang.

Indikasi lain kesiapan mereka berwirausaha juga tercermin dari kesadaran akan keniscayaan kompetisi dalam dunia bisnis sehingga $75 \%$ responden memandangnya bukan sebagai ancaman. Demikian juga dalam hal menggali gagasan usaha, bukan menjadi suatu kendala maupun penghambat ( $69 \%$ ) karena salah satu ciri wirausaha sukses adalah kemampuannya untuk selalu memunculkan gagasan baru berbisnis. Kreatifitas menjadi pembeda antara wirausahawan dengan pelaku bisnis biasa karena kreatifitaslah yang memberi nilai lebih atas suatu produk. Disisi lain kemampuan untuk membangun jaringan dengan pemasok maupun pelanggan ikut menentukan keberlangsungan bisnis secara menguntungkan. Namun demikian $60 \%$ responden berpendapat membangun jaringan lebih utama dibanding kemampuan mengkreasi suatu produk ( $40 \%$ ). Dari sudut pandang lain, aspek tertib administrasi disadari betul oleh $82 \%$ responden bahwa hal tersebut ikut menentukan keberlangsungan bisnis. Pandangan ini wajar, karena di bangku luiah mereka mendapatkan ilmu perihal peran penting administrasi sebagai bagian integral dari manajemen.

Meskipun niat berwirausaha cukup kuat dan didukung oleh beberapa persepsi positif masih juga terbersit keraguan dimana keraguan ini dipicu oleh pendapat orang tua yang mementahkan kebulatan tekad berwirausaha. Sebanyak $83 \%$ responden mengakui besarnya pengaruh pendapat orang tua, hal in terjadi karena bagaimanapun dalam kultur masyarakat Indonesia restu orang tua sangat dinanti. Barangkali karena factor tersebut maka masih sebanyak $48 \%$ responden yang mempertimbangkan untuk tetap mencari pekerjaan formal bila lulus nanti.

\section{Kesimpulan}

Motivasi berwirausaha dan menekuni profesi wirausaha di kalangan mahasiswa peserta program sangat tinggi karena mereka menyadari prospek cerah profesi ini. Status mahasiswa dengan kesibukan kuliah menjadi faktor yang membatasi gerak mereka dalam menjalankan bisnis yang sedang dirintis. Kesadaran akan kewajiban untuk menyelesaikan pendidikan tepat waktu dengan indeks prestasi tinggi memecah konsentrasi berwirausaha sehingga menjadikan tingkat kemajuan usaha terhambat. Namun demikian keyakinan mahasiswa terhadap masa depan wirausaha tidak atau belum sepenuhnya bulat, dimana hal ini tercermin dari niat mereka untuk tetap mencari pekerjaan ketika sudah lulus dan baru akan berwirausaha ketika masih juga belum mendapatkan pekerjaan yang diinginkan.

Berdasarkan analisis tersebut dapat disimpulkan bahwa program mahasiswa wirausaha belum berhasil sepenuhnya membentuk paradigma mahasiswa untuk yakin terhadap prospek profesi wirausaha sehingga belum bisa berkomitmen berwirausaha. Namun demikian masih cukup banyak mahasiswa yang 
terindikasi akan konsisten berwirausaha sehingga sedikit banyak program PMW telah memberikan kontribusi terhadap minat mahasiswa menciptakan pekerjaan sendiri.

\section{Saran}

Kegamangan mahasiswa peserta program PMW perlu disikapi dengan bijak mengingat bahwa sejatinya tujuan mahasiswa kuliah adalah mencari bekal ilmu untuk mendapatkan pekerjaan kelak. Program PMW tetap perlu dipertahankan karena sedikit banyak telah menyebarkan virus wirausaha di kalangan mahasiswa.

\section{DAFTAR PUSTAKA}

Lieli Suharti dan Hani Sirine. 2011, Faktor-faktor yang berpengaruh Terhadap Niat Kewirausahaan ; Studi Terhadap Mahasiswa Universitas Kristen Satya
Wacana Salatiga, Jurnal Manajemen dan Kewirausahaan Vol. 15 No. 2 Hal. 124 - 134.

Lutfi. 2014 , Motivasi Wirausaha Mahasiswa Administrasi Pendisikan Universitas Negeri Padang, Skripsi. Publikasi online.

Anandha A Vilathuvahna dan Taufik R Nugroho. 2015. Intensi Kewirausahaan Mahasiswa Universitas Trunojoyo Madura, Jurnal Agriekonomika, Volume 4 Nomor 1, April 2015

Sugiyono, 2013. Metode Penelitian Kombinasi. Alfabeta: Bandung

Kashir. 2012. Kewirausahaan. Penerbit Rajawali Persada: Jakarta 